\title{
CAN EFL LEARNERS' LEARNING STYLES IMPACT THEIR PERFORMANCE ON WRITING SKILL UNDER DIRECT AND INDIRECT CORRECTIVE FEEDBACKS?
}

\author{
Mojtaba Maghsoudi ${ }^{1}$ and Sahar Saeedi ${ }^{2}$
}

Abstract: This study presents the findings of an investigation of the impact of teacher error corrective feedback on 180 field-dependent/ field-independent (FD/FI) male and female pre-intermediate and advanced Iranian EFL learners writing skill. The participants were separated into two experimental groups and one control group and were asked to write three paragraphs of about 100-150 words around three different topics, each in odd days of a week; then they received direct (in experimental group 1), indirect (in experimental group 2) and no correction feedback (in control group). The results based on Mean Scores, Standard Deviation, Multivariate Analyses and 1-way ANOVA showed that there was not any significant difference between the FD/FI learners' writing skill scores who had received corrective feedback on their errors; however, as indicated by the second finding of the present study it would be better to feedback field-dependent/-independent EFL learners indirectly. It

\footnotetext{
${ }^{1}$ Motjaba Maghsoudi, Ph.D. in TEFL <maghsudim@yahoo.com> is lecturer at Farhangian University, Iran (Shahid Bahonar branch, Arak).

${ }^{2}$ Sahar Saeedi, M.A. is a student at the Department of English Language Teaching, Science and Research Branch, Islamic Azad University, Arak, Iran.
} 
156 Celt, Volume 13, Number 2, December 2013: 155 - 186

was also indicated that, learners' learning styles had made a significant change in their writing skill scores.

Key words: Error Corrective Feedback, Direct Corrective Feedback, Indirect Corrective Feedback, Learning Style, Field-dependent and Field-independent

\section{INTRODUCTION}

There is no doubt that writing is the most difficult skill for Second Language (L2) learners to master. The difficulty lies not only in generating and organizing ideas, but also in translating these ideas into readable text. The skills involved in writing are highly complex. L2 writers have to pay attention to higher level skills of planning and organizing as well as lower level skills of spelling, punctuation, word choice, and so on. The difficulty becomes even more pronounced if their language proficiency is week (Richards and Renandya 2002). However, according to Carter and Nunan (2002), even as late as the 1970s, L2 writing was not viewed as a language skill to be taught to learners. Instead, it was used as a support skill in language learning to, for example, practice handwriting, write answer to grammar and reading exercises, and write dictation. Students copied sentences or short pieces of discourse, making discrete changes in person or tense. The teaching philosophy grew directly out of audio lingual method: students were taught incrementally, error was prevented and accuracy was expected to arise out of practice with structures.

In the 1990s, writing trends and research focused on composing and revising processes, contrastive analysis/error analysis, coherence/cohesion, the process-product classroom, communicative competence, collaborative learning, computerassisted language learning (C.A.L.L.), and proficiency testing 
M. Maghsoudi and S. Saeedi, Can EFL Learning Styles Impact Writing 157

(Reid 1993). Teaching writing to advanced ELLs became a particular focus (Reid 1993). These methods and trends were in contrast to earlier methods.

In 1996, Truscott's interest in advanced ESL writing examined the question of whether grammar correction belonged in L2 writing courses, and responses and a debate to his conclusions followed. As we move further into the new millennium, it will be interesting to look back and see what kinds of trends in ESL/EFL writing has emerged. With increased state testing and standards, the emphasis on accuracy and form in writing seems to be re-emerging as a significant trend. On the other hand EFL/ESL writing teachers and researchers have never denied the important role of correct use of vocabularies in writing understandability. In that regard, the present study explores the role of grammatical, semantic and cohesion/coherence direct and indirect corrective feedback in the EFL learners' writing skill enhancement.

Lightbown and Spada define feedback as: "An indication to a learner that his or her use of the target language is incorrect. Corrective feedback can be explicit (for example, in response to the learner error 'He go'- No, you should say "goes", not "go") or implicit (for example, 'Yes, he goes to school every day'), and may or may not include meta-linguistic information (for example, "Don't forget to make the verb agree with the subject" (2006:197).

Among the strategies used in written corrective feedback are "direct" and "indirect". Direct or explicit feedback occurs when the teacher idenfies an error and provides the correct form, while indirect feedback refers to situations when the teacher indicates that an error has been made but does not provide a correction, thereby leaving the student to diagnose and correct it. Additionally, studies examining the effect of 
indirect feedback strategies have tended to make a further distinction between those that do or do not use a code. Coded feedback points to the exact location of an error, and the type of error involved is indicated with a code (for example, PS means an error in the use or form of the past simple tense). Un-coded feedback refers to instances when the teacher underlines an error, circles an error, or places an error tally in the margin, but, in each case, leaves the student to diagnose and correct the error (Bitchener, Young and Cameron 2005).

Direct corrective feedback has also included oral metalinguistic explanation, such as in the form of class discussion, a mini lesson where the rules and examples are presented, practiced and discussed or one-on-one conferences (Bitchener 2008, Bitchener and Knoch 2009).

This study (Ferris and Roberts, ibid) is important because it compared two types of indirect feedback. The findings indicate that students who received both underlining and coding did slightly better in revising their grammatical errors than those receiving underlining only, but there did not seem to be an immediate advantage to more explicit coded indirect feedback for the students in the study. Not surprisingly, both groups did better in revising errors than the control group receiving no feedback. This study provides support for indirect corrective feedback and it considers indirect corrective feedback as more likely to lead to long-term learning (Ferris and Roberts 2001).

Providing effective feedback to help learners in their writing development can be a daunting and confusing task for teachers. Particularly complex is identifying which aspects to address in a student's writing and how to do so to best help the learner improve. 
Witkin (1973, as cited in Maghsudi 2008), a pioneer in learning styles, defined learning styles in terms of a process. He argued that learning styles are concerned with the form rather than the content of the learning activity. Learning style refers to individual differences in how we perceive, think, solve problems, and learn (Maghsoudi 2008).

Witkin's work (as cited in Maghsoudi 2008) concentrated on determining to what extent a person's perception of an item was influenced by the surrounding field in which the item appeared. He wanted to determine if "some people saw the tree, while others saw the forest". According to him whereas fielddependent people see the forest, field-independent learners see the tree within the forest.

In theory, there are as many learning styles as there are learners, and the practical implication of learning styles for teaching-learning interactions are numerous. Nevertheless, in recent years, only a few of the possible number of styles have received the attention of L2 researchers; one of the most well researched areas is "field independence" (FI) or "field dependence" (FD). FI / FD refer to how people perceive and memorize information (Maghsudi 2008).

Cassidy (2004) states that field-independent learners are characterized as operating with an internal frame of reference, intrinsically motivated with self-directed goals, structuring their own learning, and defining their own study strategies. Fielddependent learners on the other hand are characterized as relying more on an external frame of reference, are extrinsically motivated, respond better to clearly defined performance goals, have a need for structuring and guidance from the instructor, and a desire to interact with other learners. 
160 Celt, Volume 13, Number 2, December 2013: 155 - 186

\section{A. Statement of the Problem and Purpose of the Study}

Teaching English second language (L2) writing differs from teaching other language skills in the way that, even as late as the 1970s, L2 writing was not viewed as a language skill to be taught to learners. Instead, it was used as a support skill in language learning to, for example, practice handwriting, write answers to grammar and reading exercises, and write dictation. And then, writing skill was considered as a passive skill that had no production and also neglected by L2 teachers and learners in L2 classrooms.

Considering writing skill as a supportive and passive skill and also neglecting this skill in the L2 learning domain has led L2 learners not to pay enough attention to their writing skill.

Research findings in L2 writing domain indicate that written corrective feedback (WCF) is one of the most frequently used techniques in English writing classes. Overall, based on the currently available evidence over the issue of WCF (See e.g. Ferris 2006, Rahimi 2009, Bitchener 2005, and Chandler 2003) concluding that feedback is effective in helping EFL (English Foreign Language) students improve the accuracy of their writing, it is likely to show that the present study seeks to determine whether written direct or indirect corrective feedback affect Iranian English learners' writing skill.

This study also aims to find out whether there is any correlation between these feedback types and learners' fielddependency/-independency, that is, to find out whether direct and indirect corrective feedbacks affect field-dependent and field-independent learners' writing skill differently. 


\section{B. Significance of the Study}

Providing feedback in a second language is vital to a student's writing development. While making errors is natural in all aspects of language learning, second language writers face unique challenges in developing writing skills (Evans, Hartshorn, McCollum, and Wolfersberger 2010). Written corrective feedback gives learners information that they need to notice their errors. Ferris (2002) suggests that students "need distinct and additional intervention from their writing teachers to make up their deficits and develop strategies for finding, correcting, and avoiding errors". However, there has been controversy around corrective feedback.

The significance of this study lies in the fact of confirming and showing the efficacy of two types of written corrective feedback (WCF) i.e. "direct" versus "indirect" feedback within a group of participants with providing feedback.

This study helps EFL learners to find out the importance of writing skill as an active and productive skill and to learn how to improve their writing skill through teacher's feedback. It also, paves the way for benefitting from the correlation between learning styles and direct and indirect corrective feedbacks.

\section{Research Questions and Hypotheses:}

To meet the aims of this study the following research question and hypotheses were formulated:

Q1: Does teacher's feedback impact EFL learners' with different learning styles differently? 
162 Celt, Volume 13, Number 2, December 2013: 155 - 186

Q2: Does teacher's direct vs. indirect corrective feedback impact Iranian EFL learners' writing skill, with different learning styles, differently?

Q3: Do EFL learners with different learning styles differ in their performance on writing skill?

H1: Regarding their learning styles, Iranian EFL learners' writing skill is influenced differently by teacher's feedback.

H2: Direct and indirect feedbacks have different impact on the writing skill of EFL learners with different learning styles.

H3: EFL learners with different learning styles differ significantly in their performance on writing skill.

\section{METHODOLOGY}

\section{A. Participants}

As it is advised by most researchers all over the world, the more the sample size, the better the results will be, therefore, the present researcher did her best to expand the sample size of subjects in current project accordingly.

180 male and female pre-intermediate Iranian EFL learners in the age range of 15 to 20 at Samin and AllamehTabatabaei Institute of Boroujerd (one of the cities of Lurestan province of Iran) were randomly chosen and asked to participate in this study.

The randomization process was exploited to grantee the maximum group homogeneity; however, they were homogeneous in terms of age, gender, proficiency level, type of institute, the method used at institute and number of hours devoted to teaching. 
Further filtering of subjects was done based on the scores of the Transparency Test and the Learning Style Test. Only those subjects who scored the intermediate level scores were discarded from this study.

These subjects were classified in 3 groups of 60 and have been treated as two experimental groups and one control group. Experimental group 1 has received "Direct corrective feedback" and experimental group 2 has received "Indirect corrective feedback". And no error corrective feedback was given to control group.

Subjects have been also homogenized based on age, gender and level of general English proficiency through a background questioner and the Transparency test respectively. They were also controlled based on their learning styles (fielddependency-independency) through Group Imbedded Figure Test.

\section{B. Instruments}

The different instruments used in this study include:

\section{A Background Questionnaire}

In order to elicit participants' background information, a background questioner including participants' name, age, and gender was located at the top of the Group Imbedded Figure Test, which was used to investigate learners' fielddependency/field-independency.

\section{A General English Proficiency Test (Transparency Test)}

This test has been composed of multiple-choice cloze passage, vocabulary, grammar, and reading comprehension 
sections. In order to have a reliable test of proficiency at the piloting stage the test was given to 15 students, who were selected randomly, and its reliability was estimated through the K-R21 formula as .85 and then the test was found reliable for the purpose of this study.

The time allotted for taking this test was also determined at the piloting stage as 40 minutes. Duration of the test was estimated by calculating the time spent by the fastest and the slowest students in answering the test divided by 2 . Thus, the time allotted for the test was:

$$
\frac{50+30}{2}=40
$$

\section{$\underline{\text { 3. Learning Style Test }}$}

A number of instruments have been developed to measure a person's learning style. One of the easiest to administer, especially in group situations, is the Group Imbedded Figure Test (GEFT), (Witkin, Oltman, Raskin, and Karp, 1971). The GEFT is a perceptual test, which requires the subjects to locate a figure within a larger complex figure. The GEFT which comprises of 18 complex figures can be administered in 20 minutes and can be quickly scored using answer templates from the test distributer.

This test is designed to distinguish field-independent from field-dependent cognitive types; a rating which is claimed to be value-neutral. Field-independent people tend to be more autonomous when it comes to the development of restructuring skills; that is, those skills required during technical tasks with which the individual is not necessarily familiar. They are however less autonomous in the development of interpersonal skills (Maghsoudi, 2008). 
M. Maghsoudi and S. Saeedi, Can EFL Learning Styles Impact Writing 165

4. An Error Correction Checklist

An Error Correction Checklist (See Appendix A) was developed to identify writing skills needed for EFL preintermediate and advanced writers. This checklist is developed by the researcher and includes 20 skills classified under four categories: Paragraph organization, Mechanics of writing, Language use, and cohesion/coherence. The score devoted to each skill is based on the students' level of proficiency and the given feedback. The content of this checklist was induced from Salem Saleh Khalaf Ibnian (2011) and, based on the adopt and adaptation method, was revised by the researcher of the present study so that it might meet the aim of this study. Ibnian (ibid) checklist included 16 skills classified under four categories including: content and organization, language use, mechanics of writing, and creative abilities. As cited in Chandler (2003) Azar's Guide for Correcting Compositions (1998) categorizes errors as 14 skills : singular-plural, word form, word choice, verb tense, add or omit a word, word order, incomplete sentence, spelling, punctuation, capitalization, article, meaning not clear, and run-on sentence. Chandler (2003) has added verb voice (active versus passive) in addition to verb tense, word division in addition to spelling, and sentence structure in addition to run-on sentences and fragments, categories of idiom, awkward (not grammatically incorrect but quite infelicitous stylistically), subject-verb agreement, repetition or redundancy, pronoun, and need for new paragraph in order to cover all the errors subjects made even though most of them were not frequent. Ferries \& Roberts (2001) used only five categories.

5. Pre/Post Paragraph Writing Test and its Scoring Scale

Subjects of both experimental and control groups have been asked to write three paragraphs around three different 
topics (Topic 1: How do you help others? Topic 2: How computers affect your free time? Topic 3: What are the traffic problems in your hometown? how can you solve them?), each with two days interval in both pre-test and post-test phases of the study. The topics were chosen based on the most frequent topics used for writing skill in New Interchange course books used for EFL learning in Iran English institutes. It was also tried not to choose gender- based topics to prevent the interference of the gender variable. According to the Error correction checklist subjects' paragraphs were scored out of 50 points. (See Appendix A). The time allotted for writing a paragraph was determined at the piloting stage as 50 minutes. Its duration was estimated by calculating the time spent by the fastest and the slowest students in writing a paragraph of about 100 to 150 words divided by 2 . Thus, the time allotted for the test was:

$$
\frac{65+35}{2}=50
$$

\section{Design and Procedures}

This study was implemented on the basis of a true experimental design. The reasons behind choosing such a design are:

1. Versus experimental group a control group is available;

2. The subjects are selected and assigned to the groups randomly;

3 . There is a treatment to have further comparison between preand post-test results.

To achieve the objectives of this study the following procedures were conducted by the researcher: 
M. Maghsoudi and S. Saeedi, Can EFL Learning Styles Impact Writing 167

1. Development of the Background Questionnaire and the General English Proficiency Test (Transparency Test) along with their administration.

2. Development of the Error Correction Checklist and administration of Learning Style test (Group Imbedded Figure Test).

3. Asking learners of all 3 groups (two experimental and one control) to write three paragraphs including around 100-150 words around three different topics, discussed in the earlier section, in odd days of a week. This phase was the pre-test phase of the study.

4. Giving direct corrective feedback to experimental group 1 and indirect corrective feedback to experimental group 2 . No error corrective feedback was given to control group.

5. Repeating the step 3 of the procedure, that is, asking subjects to rewrite three paragraphs including around 100150 words around the same topics in the pre-test phase, in odd days of a week, after a 10 days interval. This phase was the post-test phase of the study.

6. Analysis of collected data based on Mean Scores, Standard Deviation and Repeated Measure of Variance, Multivariate Tests and 1-way ANOVA.

\section{RESULTS AND DISCUSSION}

This section presents, analyzes, and discusses the results of the study. There were three sources of data for the study: 1) the Learning Style Test (the Group Imbedded Figure Test), 2) the General English Proficiency Test (the Transparency Test), and 3) Writing Paragraphs. 


\section{A. The First Hypothesis}

To investigate the effect of teacher's corrective feedback on writing skills of Iranian EFL learners with different learning styles (field-dependent/-independent) because of having two dependent variables of writing skill( pre-test and post-test), the data were analyzed based on Repeated Measures of variance. On the basis of their scores from the learning style test (the GEFT test), the subjects were first divided into two groups, these are:

1. Field-independent: Those subjects who scored 1 Standard deviation above the Mean (M+1 SD), and;

2. Field-dependent: Those subjects who scored 1 Standard deviation below the Mean (M-1 SD).

The following table (Table 1) shows the number of subjects within each dependent variable (the corrective feedback variable and the learning style variable). Based on this table, 84 learners received corrective feedback and 42 learners received no corrective feedback. Also 63 learners were field-dependent and 63 learners were field-independent.

\begin{tabular}{|c|c|c|c|}
\hline & & Value Label & $\mathrm{N}$ \\
\hline \multirow[t]{2}{*}{ Feedback } & 1 & Feedback & 84 \\
\hline & 3 & Control & 42 \\
\hline \multirow[t]{2}{*}{ Learning style } & 1 & Field -dependent & 63 \\
\hline & 2 & Field -independent & 63 \\
\hline
\end{tabular}

\section{Table 1:}

Between Subject Factors

The next table(Table 2) indicates the data analyses based on the pre-test/post-test mean scores and standard deviation fortheFD/FI learners in both feedback and control groups. 
M. Maghsoudi and S. Saeedi, Can EFL Learning Styles Impact Writing169

\begin{tabular}{|c|c|c|c|c|c|}
\hline & $\begin{array}{l}\text { Feedba } \\
\text { ck }\end{array}$ & $\begin{array}{l}\text { Learning } \\
\text { style }\end{array}$ & Mean & $\begin{array}{c}\text { Std. } \\
\text { Deviati } \\
\text { on }\end{array}$ & $\mathrm{N}$ \\
\hline \multirow[t]{9}{*}{$\begin{array}{l}\text { Pre- } \\
\text { Test }\end{array}$} & \multirow[t]{3}{*}{$\begin{array}{l}\text { Feedba } \\
\text { ck }\end{array}$} & $\begin{array}{l}\text { Field - } \\
\text { dependent }\end{array}$ & 18.8214 & 4.73643 & 42 \\
\hline & & $\begin{array}{l}\text { Field - } \\
\text { independent }\end{array}$ & 21.1250 & 4.50246 & 42 \\
\hline & & Total & 19.9732 & 4.73691 & 84 \\
\hline & \multirow[t]{3}{*}{ Control } & $\begin{array}{l}\text { Field - } \\
\text { dependent }\end{array}$ & 18.4643 & 4.79080 & 21 \\
\hline & & $\begin{array}{l}\text { Field - } \\
\text { independent }\end{array}$ & 21.0952 & 4.77590 & 21 \\
\hline & & Total & 19.7798 & 4.90868 & 42 \\
\hline & \multirow[t]{3}{*}{ Total } & $\begin{array}{l}\text { Field - } \\
\text { dependent }\end{array}$ & 18.7024 & 4.71888 & 63 \\
\hline & & $\begin{array}{l}\text { Field - } \\
\text { independent }\end{array}$ & 21.1151 & 4.55673 & 63 \\
\hline & & Total & 19.9087 & 4.77604 & 126 \\
\hline \multirow[t]{9}{*}{$\begin{array}{l}\text { Post- } \\
\text { Test }\end{array}$} & \multirow[t]{3}{*}{$\begin{array}{l}\text { Feedba } \\
\text { ck }\end{array}$} & $\begin{array}{l}\text { Field - } \\
\text { dependent }\end{array}$ & 30.8810 & 5.57768 & 42 \\
\hline & & $\begin{array}{l}\text { Field - } \\
\text { independent }\end{array}$ & 33.1786 & 5.64317 & 42 \\
\hline & & Total & 32.0298 & 5.69512 & 84 \\
\hline & \multirow[t]{3}{*}{ Control } & $\begin{array}{l}\text { Field - } \\
\text { dependent }\end{array}$ & 21.2833 & 4.93073 & 21 \\
\hline & & $\begin{array}{l}\text { Field - } \\
\text { independent }\end{array}$ & 25.0595 & 5.00119 & 21 \\
\hline & & Total & 23.1714 & 5.26425 & 42 \\
\hline & \multirow[t]{3}{*}{ Total } & $\begin{array}{l}\text { Field - } \\
\text { dependent }\end{array}$ & 27.6817 & 7.01539 & 63 \\
\hline & & $\begin{array}{l}\text { Field - } \\
\text { independent }\end{array}$ & 30.4722 & 6.63418 & 63 \\
\hline & & Total & 29.0770 & 6.94286 & 126 \\
\hline
\end{tabular}

Table 2:

Group Statistics 
Now, to investigate the significance of the interactive effect of the dependent variables (teacher corrective feedback and learning style), the following table (Table 3) containing the multivariate analysis, has been used:

\begin{tabular}{|c|c|c|c|c|c|c|}
\hline \multicolumn{2}{|l|}{ Effect } & Val & $\mathrm{F}$ & Hypoth & Error df & Sig. \\
\hline Time & $\begin{array}{l}\text { Pillai's } \\
\text { Trace }\end{array}$ & .886 & $\begin{array}{r}950 . \\
991 \\
\end{array}$ & 1.000 & 122.000 & .000 \\
\hline $\begin{array}{l}\text { Time } \\
* \\
\text { Feedb } \\
\text { ack }\end{array}$ & $\begin{array}{l}\text { Pillai's } \\
\text { Trace }\end{array}$ & .710 & $\begin{array}{r}299 . \\
189\end{array}$ & 1.000 & 122.000 & .000 \\
\hline $\begin{array}{l}\text { Time } \\
* \\
\text { Learn } \\
\text { ing } \\
\text { style }\end{array}$ & $\begin{array}{l}\text { Pillai's } \\
\text { Trace }\end{array}$ & .010 & $\begin{array}{r}1.29 \\
3\end{array}$ & 1.000 & 122.000 & .258 \\
\hline $\begin{array}{l}\text { Time } \\
* \\
\text { Feedb } \\
\text { ack * } \\
\text { Learn } \\
\text { ing } \\
\text { style }\end{array}$ & $\begin{array}{l}\text { Pillai's } \\
\text { Trace }\end{array}$ & .011 & $\begin{array}{r}1.32 \\
0\end{array}$ & 1.000 & 122.000 & .253 \\
\hline
\end{tabular}

Table 3:

The Multivariate Analysisfor the interactive effect of teacher corrective feedback and learning style

Based on the Sig amount (Sig=.000) for the effect of the writing skill variable in the first row, it was concluded that this effect is significant at any error level. In other words, learners writing skill score in the post-test phase has improved comparing to the pre-test phase score. Also according to the Sig amount $(\mathrm{Sig}=.000)$ for the interactive effect of the teacher corrective feedback and writing skill variables in the second row it can be observed that this effect is also significant at any 
error level. In other words, there is a significant different between these two groups, that is, based on the mentioned mean scores in the table 4, the feedback group has outperformed the control group. However, based on the Sig ( $\mathrm{Sig}=.258)$ for the interactive effect of writing skill improvement and learning styles variable in the third row, it can be concluded that this effect is not significant at the error level of .05 , that is there is no significant difference between these two groups. In other words, there isn't any difference between the FD/FI learners writing skill scores in pre-test ant post-test phases. And based on the Sig ( $\mathrm{Sig}=.253$ ) for the interactive effect of writing skill improvement and learning styles variables in both feedback and control group in the fourth row, it can be concluded that this effect is not significant at the error level of .05, that is there is no significant difference between these two groups. In other words, there isn't any difference between the FD/FI learners writing skill scores in pre-test ant post-test phases.

For a better understanding of the above report, the graphical presentation is presented. The following graph in the left side shows the estimated marginal means of writing skill scores of FD/FI learners in both feedback and control groups in the pre-test phase, and the graph in the right side shows the estimated marginal means of writing skill scores of FD/FI learners in both feedback and control groups in the post-test phase.

In Graph 1 you can see in the pre-test phase that there is no difference between the estimated marginal mean scores of the writing skills of learners in teacher feedback group and those in the control group (green line graph on the first). There is no difference also between the estimated marginal mean scores of the writing skills of field-dependent learners in the 
172 Celt, Volume 13, Number 2, December 2013: 155 - 186

teacher feedback group and the control group (purple line graph on the first) in the pre-test phase.
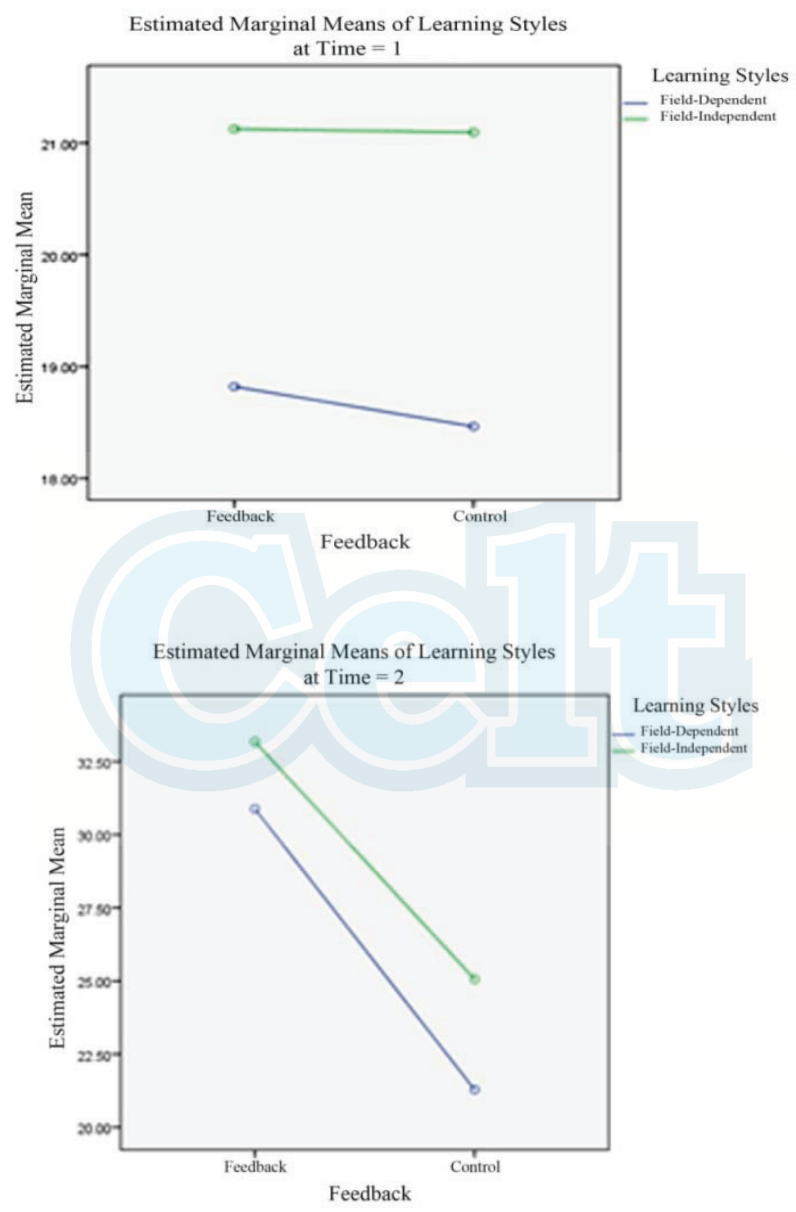

Graph 1:

Linear chart of the mean difference between FD/FI learners writing skill scores of feedback and control groups in pre and post-test phases 
However, there is a difference between the estimated marginal mean scores of the pre-test writing skills scores of fieldindependent learners and field-dependent ones (the difference between green and purple lines in the first diagram).

Concerning the next graph, you can see that there is a difference between the estimated marginal means of fieldindependent learners writing skills post-test scores in the teacher feedback group and the control group (green line graph on the second). There is also a difference between the estimated marginal mean scores of the field-dependent learners post-test writing skills scores in the teacher feedback group and the control group (purple line chart in the second). However, there is no difference between the estimated marginal mean scores of the field- independent learners and field-dependent ones' posttest writing skills scores (between green and purple lines on the second graph).

When the first and the second graphs of Graph 1, are compared, there is no significant difference between the estimated marginal means of the field-dependent and fieldindependent learners' post-test writing skills scores, that is, the interactive effects of the two independent variables (teacher's feedback and learning style) on the dependent variable (writing skill) are not meaningful and significant. According to above mentioned report, the first hypothesis of this study is rejected.

\section{B. The Second Hypothesis}

To investigate the effect of teacher's direct vs. indirect corrective feedback on writing skills of Iranian EFL learners with different learning styles (field-dependent/-independent) because of having two dependent variables of writing skill( pre- 
174 Celt, Volume 13, Number 2, December 2013: 155 - 186

test and post-test), the data were analyzed based on Repeated Measures of Variance.

The following table (Table 4) shows the number of subjects within each dependent variable (groups that receive direct corrective feedback and indirect corrective feedback variable and the learning style variable). Based on this table, 42 learners received direct corrective feedback and 42 learners received indirect corrective feedback. Also 42 learners were field-dependent and 42 learners were field-independent.

\begin{tabular}{|l|l|l|r|}
\hline \multicolumn{2}{|c|}{} & \multicolumn{1}{|c|}{ Value Label } & $\mathrm{N}$ \\
\hline \multirow{2}{*}{ Group } & 1 & Direct Feedback & 42 \\
\cline { 2 - 4 } & 2 & Indirect Feedback & 42 \\
\hline \multirow{2}{*}{ Learning Style } & 1 & Field -dependent & 42 \\
\cline { 2 - 4 } & 2 & Field -independent & 42 \\
\hline
\end{tabular}

\section{Table 4:}

Between-Subjects Factors

The next table (Table 5) indicates the data analyses based on the pre-test/post-test mean scores and standard deviation for the FD/FI learners who received direct and indirect corrective feedback.

\begin{tabular}{|c|c|c|c|c|c|}
\hline & Group & Method & Mean & $\begin{array}{c}\text { Std. } \\
\text { Deviation }\end{array}$ & $\mathrm{N}$ \\
\hline \multirow[t]{6}{*}{$\begin{array}{l}\text { Pre- } \\
\text { Test }\end{array}$} & \multirow[t]{3}{*}{$\begin{array}{l}\text { Direct } \\
\text { Feedback }\end{array}$} & $\begin{array}{l}\text { Field - } \\
\text { dependent }\end{array}$ & 18.6071 & 4.91399 & 21 \\
\hline & & $\begin{array}{l}\text { Field - } \\
\text { independent }\end{array}$ & 21.1310 & 4.54328 & 21 \\
\hline & & Total & 19.8690 & 4.84555 & 42 \\
\hline & \multirow[t]{3}{*}{$\begin{array}{l}\text { Indirect } \\
\text { feedback }\end{array}$} & $\begin{array}{l}\text { Field - } \\
\text { dependent }\end{array}$ & 19.0357 & 4.66321 & 21 \\
\hline & & $\begin{array}{l}\text { Field - } \\
\text { independent }\end{array}$ & 21.1190 & 4.57344 & 21 \\
\hline & & Total & 20.0774 & 4.68212 & 42 \\
\hline
\end{tabular}


M. Maghsoudi and S. Saeedi, Can EFL Learning Styles Impact Writing 175

\begin{tabular}{|c|c|c|c|c|c|}
\hline & \multirow[t]{3}{*}{ Total } & $\begin{array}{l}\text { Field - } \\
\text { dependent }\end{array}$ & 18.8214 & 4.73643 & 42 \\
\hline & & $\begin{array}{l}\text { Field - } \\
\text { independent }\end{array}$ & 21.1250 & 4.50246 & 42 \\
\hline & & Total & 19.9732 & 4.73691 & 84 \\
\hline \multirow[t]{9}{*}{$\begin{array}{l}\text { Post- } \\
\text { Test }\end{array}$} & \multirow[t]{3}{*}{$\begin{array}{l}\text { Direct } \\
\text { Feedback }\end{array}$} & $\begin{array}{l}\text { Field - } \\
\text { dependent }\end{array}$ & 29.9286 & 4.41103 & 21 \\
\hline & & $\begin{array}{l}\text { Field - } \\
\text { independent }\end{array}$ & 31.3452 & 4.26136 & 21 \\
\hline & & Total & 30.6369 & 4.34320 & 42 \\
\hline & \multirow[t]{3}{*}{$\begin{array}{l}\text { Indirect } \\
\text { feedback }\end{array}$} & $\begin{array}{l}\text { Field - } \\
\text { dependent }\end{array}$ & 31.8333 & 6.51265 & 21 \\
\hline & & $\begin{array}{l}\text { Field - } \\
\text { independent }\end{array}$ & 35.0119 & 6.32973 & 21 \\
\hline & & Total & 33.4226 & 6.54382 & 42 \\
\hline & \multirow[t]{3}{*}{ Total } & $\begin{array}{l}\text { Field - } \\
\text { dependent }\end{array}$ & 30.8810 & 5.57768 & 42 \\
\hline & & $\begin{array}{l}\text { Field - } \\
\text { independent }\end{array}$ & 33.1786 & 5.64317 & 42 \\
\hline & & Total & 32.0298 & 5.69512 & 84 \\
\hline
\end{tabular}

Table 5:

Group Statistics

Table 5 indicates that the mean score and standard deviation for the $\boldsymbol{F D}$ learners who received direct feedback in pre-test phase were 18.60 and 4.91 respectively, and mean score and standard deviation for the $\boldsymbol{F I}$ learners who received direct feedback in the same phase were 21.13 and 4.54 respectively. Also, the mean score and standard deviation for the $\boldsymbol{F D}$ learners who received indirect feedback in pre-test phase were 19.03 and 4.66, and these statistics for $\boldsymbol{F I}$ learners who received indirect feedback in the same phase were 21.11 and 4.57 respectively. In the post-test phase, the mean score and standard deviation for the $\boldsymbol{F D}$ learners who received direct feedback were 29.92 and 4.41, and mean score and standard deviation for the $\boldsymbol{F I}$ learners who received direct feedback in 
176 Celt, Volume 13, Number 2, December 2013: 155 - 186

the same phase were 31.34 and 4.26 respectively. Mean score and standard deviation for $\boldsymbol{F D}$ learners who received indirect feedback in post-test phase were 31.83 and 6.51, and these statistics for $\boldsymbol{F I}$ learners who received indirect feedback in the same phase were 35.01 and 6.32 respectively.

To examine the significance of the interactive effect between the independent variables (learning style and direct/indirect feedback), the following table (Table 6) can be helpful:

\begin{tabular}{|c|c|c|c|c|c|c|}
\hline \multicolumn{2}{|l|}{ Effect } & Valu & F & Hypothesi & Error & Sig. \\
\hline Time & $\begin{array}{l}\text { Pillai' } \\
\text { s } \\
\text { Trace } \\
\end{array}$ & .969 & $\begin{array}{r}2484.27 \\
2\end{array}$ & 1.000 & $\begin{array}{r}80.00 \\
0\end{array}$ & $\begin{array}{r}.00 \\
0\end{array}$ \\
\hline $\begin{array}{l}\text { Time * } \\
\text { Group }\end{array}$ & $\begin{array}{l}\text { Pillai' } \\
\text { s } \\
\text { Trace }\end{array}$ & .262 & 28.382 & 1.000 & $\begin{array}{r}80.00 \\
0\end{array}$ & $\begin{array}{r}.00 \\
0\end{array}$ \\
\hline $\begin{array}{l}\text { Time * } \\
\text { Learnin } \\
\text { g Styles }\end{array}$ & $\begin{array}{l}\text { Pillai' } \\
\text { s } \\
\text { Trace } \\
\end{array}$ & .000 & .000 & 1.000 & $\begin{array}{r}80.00 \\
0\end{array}$ & $\begin{array}{r}.99 \\
0\end{array}$ \\
\hline $\begin{array}{l}\text { Time * } \\
\text { Group } \\
* \\
\text { Learnin } \\
\text { g Styles }\end{array}$ & $\begin{array}{l}\text { Pillai' } \\
\text { s } \\
\text { Trace }\end{array}$ & .061 & 5.181 & 1.000 & $\begin{array}{r}80.00 \\
0\end{array}$ & $\begin{array}{r}.02 \\
6\end{array}$ \\
\hline
\end{tabular}

Table 6:

Multivariate Analysis for the interactive effect between learning style and direct/indirect feedback

Based on the Sig amount (Sig=.000) for the effect of the writing skill variable in the first row, it was concluded that this effect is significant at any error level. In other words, learners 
writing skill score in the post-test phase has improved comparing to the pre-test phase score.

Also according to the Sig amount $(\mathrm{Sig}=.000)$ for the interactive effect of the writing skill score and direct/indirect corrective feedback variables in the second row it can be observed that this effect is also significant at any error level. In other words, there is a significant different between these two groups, that is, based on the mentioned mean scores in the table 7 , those subjects who have received indirect feedback have had a better performance than those who have received direct feedback.

However, based on the Sig (Sig=.99) for the interactive effect of writing skill improvement and learning styles variables in the third row, it can be concluded that this effect is not significant at the error level of .05 , that is there is no significant difference between these two groups. In other words, there isn't any difference between the FD/FI learners writing skill scores in pre-test ant post-test phases. And based on the Sig ( $\mathrm{Sig}=.02)$ for the interactive effect of writing skill improvement and learning styles variables in direct feedback group and indirect feedback group in the fourth row, it can be concluded that this effect is significant at the error level of .05, that is there is a significant difference between these two groups. In other words, there is a difference between the FD/FI learners writing skill scores who have received direct/indirect corrective feedback in pre-test ant post-test phases. For a better understanding of the above report, the graphical presentation is presented. The following graph (Graph 2) in the left side shows the estimated marginal means of writing skill scores of FD/FI learners who received direct/indirect feedback in the pre-test phase, and the graph in the right side shows the estimated 
marginal means of writing skill scores of FD/FI learners who received direct/indirect feedback in the post-test phase.
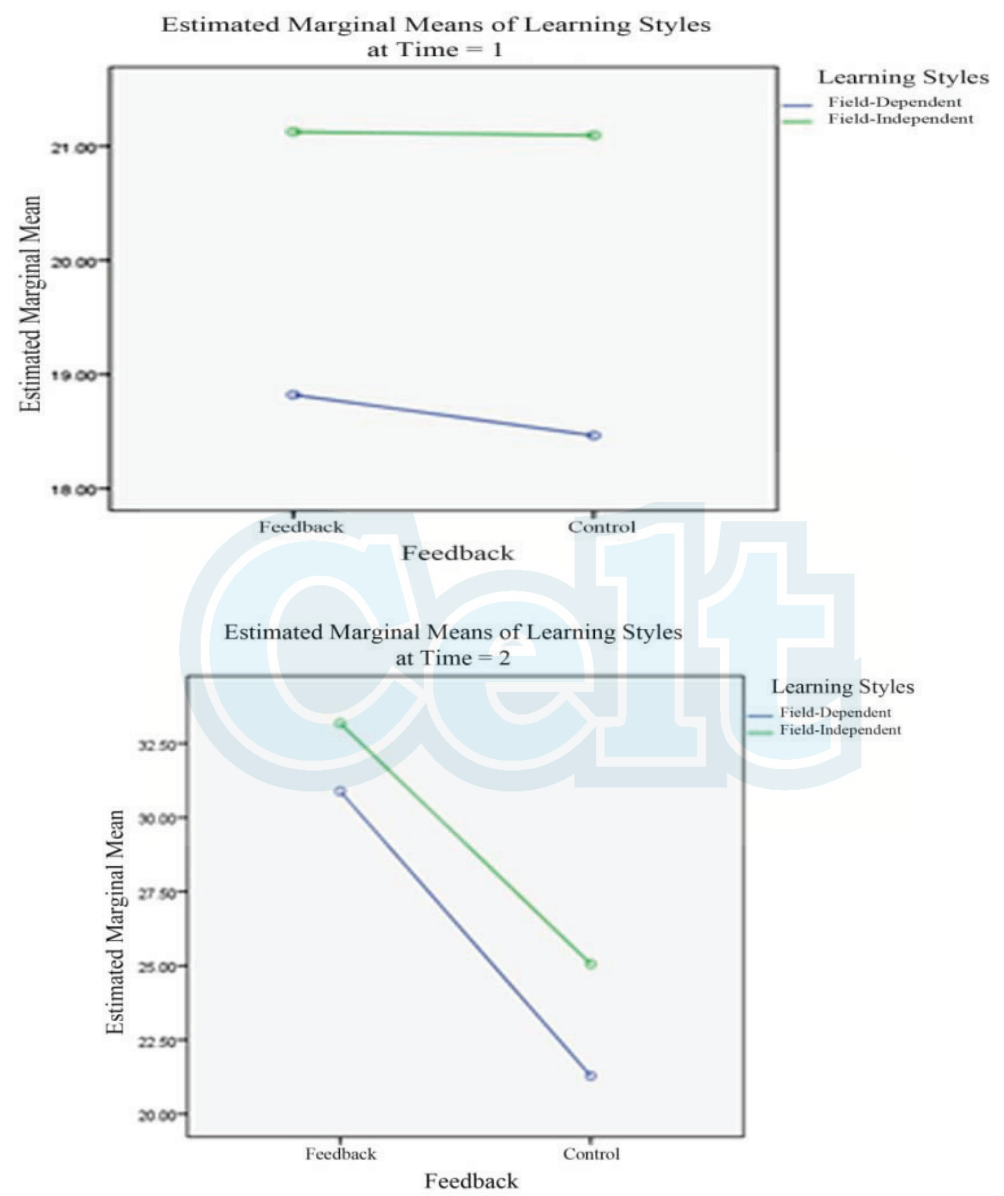

Graph 2:

Linear chart of the mean difference between FD/FI learners writing skill scores of feedback and control groups in pre-test and post-test phases 
In the first diagram above you can see that in the pre-test phase, there isn't any difference between the estimated marginal mean scores of the writing skills of FI learners in direct and indirect feedback groups (green line in the first graph). There is no difference also between the estimated marginal mean scores of the writing skills of FD learners in the direct and indirect feedback groups (purple line in the left graph) in the same phase. However, there is a difference between the estimated marginal mean scores of the pre-test writing skills scores of field- independent learners and fielddependent ones (the difference between green and purple lines in the first diagram).

Concerning the second diagram above you can see that there is a difference between the estimated marginal means of field-independent learners writing skills post-test scores in the indirect feedback group and the direct group (green line in the second graph). There is also a difference between the estimated marginal mean scores of the field-dependent learners post-test writing skills scores in the direct and indirect feedback group (purple line in the second graph). There is a difference between the estimated marginal mean scores of the field- independent learners and field-dependent ones' post-test writing skills scores (between green and purple lines on the second graph).

Now when the first and the second graphs are compared, there is also, a significant difference between the estimated marginal means of the field-dependent and field-independent learners' post-test writing skills scores, that is, the interactive effects of the two independent variables (teacher's direct and indirect corrective feedback and learning style) on the dependent variable (writing skill) are meaningful and significant. According to above mentioned report, the second hypothesis of this study is accepted. 
180 Celt, Volume 13, Number 2, December 2013: 155 - 186

Based on the above results, there is also a difference between the post-test writing scores of the FD learners who had received direct feedback and those who had received the indirect one, but this difference is not as significant as the difference between FI learners who had received indirect feedback and those who had received direct feedback. In fact, FI learners who had received indirect feedback out-performed those FI learners who had received direct feedback. Therefore, it can be concluded that FD learners benefit from different sorts of corrective feedback the same, while, FI learners benefit from the indirect feedback more than the direct one.

\section{The Third Hypothesis}

To investigate the effect of learning style on writing skills of Iranian EFL learners because of having two dependent variables of writing skill( pre-test and post-test), the data were analyzed based on Repeated Measures of variance.

The following table (Table 7) indicates the data analyses based on the pre-test/post-test mean scores and standard deviation for the FD/FI learners.

\begin{tabular}{|l|r|r|r|}
\hline \multicolumn{2}{|c|}{ Mean } & $\begin{array}{c}\text { Std. } \\
\text { Deviation }\end{array}$ & $\mathrm{N}$ \\
\hline Dependent Field & 18.7024 & 4.71888 & 63 \\
\hline Independent Field & 21.1151 & 4.55673 & 63 \\
\hline Total & 19.9087 & 4.77604 & 63 \\
\hline Dependent Field & 27.6817 & 7.01539 & 63 \\
\hline Independent Field & 30.4722 & 6.63418 & 126 \\
\hline Total & 29.0770 & 6.94286 & \\
\hline
\end{tabular}

Table 7:

Group Statistics 
The next table (Table 8) indicates the results of the 1way ANOVA for the significance of the interactive effect between learning style and writing skill.

\begin{tabular}{|l|r|r|r|r|r|}
\hline Source & \multicolumn{1}{|c|}{$\begin{array}{c}\text { Type IV } \\
\text { Sum of } \\
\text { Squares }\end{array}$} & df & \multicolumn{1}{c|}{$\begin{array}{c}\text { Mean } \\
\text { Square }\end{array}$} & F & Sig. \\
\hline Intercept & 151174.813 & 1 & 151174.813 & 2691.906 & .000 \\
\hline Method & 426.400 & 1 & 426.400 & 7.593 & .007 \\
\hline Error & 6963.719 & 124 & 56.159 & & \\
\hline
\end{tabular}

Table 8:

Results of 1-way ANOVA for the significance of the interactive effect between learning style and writing skill.

According to the sig amount in the second row of table 8 $(\mathrm{sig}=.000<.05)$, it is indicated that this effect is significant at any error level. Therefore, there is a significant interaction between writing skill scores and learning styles of the Iranian EFL learners. In other words, there is a significant difference between the mean scores of the FD/FI EFL learners writing skill scores.

For a better understanding of the above report, the graphical presentation is presented. The following graph (Graph 3) shows the estimated marginal means of writing skill scores of FD/FI learners in the pre-test and post-test phases. The graph indicates there is a meaningful difference between the writing skill scores of the FD/FI learners in the pre-test and post-test, and learners' learning styles has made a significant change in the their writing skill scores. Therefore the third hypothesis of the present study stands accepted. 


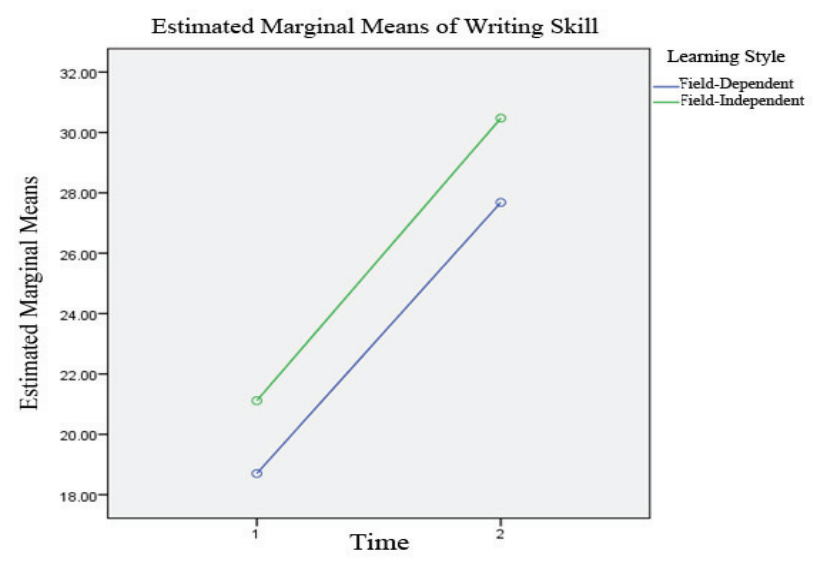

Graph 3:

Estimated Marginal Means of writing skill scores of FD/FI learners in the pre-test and post-test phases.

\section{CONCLUSION}

According to Hyland (2008), the cognitive dimension of learning styles distinguishes field -independent learners who are mainly analytic and prefer instruction that emphasizes rules, from field-dependent students who flourish in cooperative, experiential classrooms with plenty of interaction and feedback on their writing. While, the results of the present study indicate that there isn't any significant difference between the FD/FI learners' writing skill scores who has received corrective feedback on their errors. Therefore, it is suggested that, to feedback EFL learners on their writing products, teachers do not need to take their learning styles into account; however, as indicated by the second finding of the present study it would be better to feedback field-dependent/-independent EFL learners indirectly. 
According to Ferris and Roberts (2001) and Bitchener (2005), indirect feedback is more effective than direct feedback because it requires the learner to engage in guided learning and problem solving which may contribute to long-term learning. According to the third hypotheses of this study, there is a meaningful difference between the writing skill scores of the FD/FI learners in the pre-test and post-test, and learners' learning styles has made a significant change in the their writing skill scores. Therefore, it can be concluded that, because EFL learners' writing skill is affected by their difference in learning styles, EFL teachers would better to know their students' specific learning styles in order to be able to provide them with those techniques and strategies of writing skill which is more compatible with their individual styles of learning.

\section{REFERENCES}

Ahmadi et al. Procedia - Social and Behavioral Sciences, Vol. 46, 2012:2590-2595.

Ashwell, T. "Patterns of teacher response to student writing in a multiple-draft composition classroom: Is content feedback followed by form feedback the best method?" In Journal of Second Language Writing 9, 2000:227-257.

Bitchener, J. "Evidence in support of written corrective feedback". In Journal of Second Language Writing, Vol. 17, 2008:102-118.

Bitchener, J. and U. Knoch. "The value of a focused approach to written corrective feedback". In ELT Journal, Vol. 63, No. 3, 2008:204-211.

Bitchener, J. and U. Knoch. "The relative effectiveness of different types of direct written corrective feedback". System, Vol. 37, 2009:322-329. 
Bitchener, J. and U. Knoch. "The contribution of written corrective feedback to language development: A ten month investigation". In Applied Linguistics, Vol. 31, 2010:193-214.

Bitchener, J., S. Young, and D. Cameron. "The effects of different types of corrective feedback in ESL student writing". In Journal of Second Language Writing, Vol. 14, 2005:191 205.

Carter, R. and D. Nunan (eds.). The Cambridge Guide to Teaching English to Speakers of Other Languages. Cambridge: Cambridge University Press, 2002.

Chandler, J. "The efficacy of various kinds of error feedback for improvement in the accuracy and fluency of L2 student writing". In Journal of Second Language Writing, Vol. 12, 2003:267-296.

Ellis, R. "A typology of written corrective feedback types". In ELT Journal, Vol. 63, No. 2, 2009:97-107.

Ellis, R.,Y. Sheen,M. Murakami, and H. Takashima. "The Effects of Focused and Unfocused Written Corrective Feedback on Japenese University Students' use of English Articles in Narratives". In System, Vol. 36, 2008:353-371.

Evans, N.W., K.J. Hartshorn, R.M. McCollum dan M. Wolfersberger. "Contextualizing corrective feedback in second language writing pedagogy". In Language Teaching Research, Vol. 14,2010:445-463.

Fathan, A.K and E. Walley. "Teacher response to student writing: Focus on form versus content". In B.Kroll. Second Language Writing, Cambridge UK: CUP, 1990:57-68.

Ferris, D. Treatment of error in second language student writing. Ann Arbor: University of Michigan Press, 2002.

Ferris, D. "Preparing Teachers to Respond to Students Writings".In Journal of Second Language Writing, Vol. 16, No. 3, 2007:165-193. 
M. Maghsoudi and S. Saeedi, Can EFL Learning Styles Impact Writing 185

Ferris, D. "Second language writing research and written corrective feedback in SLA: Intersections and practical application". In Studies in Second Language Acquisition, Vol. 32, 2010:181201.

Ferris, D. and B. Roberts. "Error Feedback in L2 Writing Classes. How explicit does it need to be?" In Journal of Second Language Writing, Vol. 10, No. 3, 2001:161-184.

Ferris, D.R."Does error feedback help student writers? New evidence on the short- and long-term effects of written error correction". In K. Hyland and F. Hyland (Eds.), Feedback in second language writing: Contexts and issues. Cambridge: Cambridge University Press, 2006:81-104,

Ferris, D.R."The case for grammar correction in L2 writing classes: A response to Truscut, J." In Journal of Second Language Writing, Vol.8, 1996:1-10.

Liang, Y."The effects of error feedback in second language writing”. In Second Language Acquisition and Teaching, Vol. 15, 2008:65-79.

Lightbown, P. and N. Spada. How languages are learned, $3^{\text {rd }}$ ed. Oxford: Oxford University Press, 2006

Pan, Y. "The Effect of Teacher Error Feedback on the Accuracy of EFL Students Writing”. In TEFLIN Journal, Vol. 21, 2010.

Rahimi, M. “The role of teacher's corrective feedback in improving Iranian EFL learners' writing accuracy over time: is learner's mother tongue relevant?'In Reading and Writing, Vol. 22, No. 2,2009:219-243.

Richards, J.C. and W.A. Renandya (eds.). "Methodology in Language Teaching; An Anthology of Current Practice". Cambridge: Cambridge University Press, 2002.

Saeedi, S. and M. Maghsoudi."Can direct corrective feedback in learners' mother tongue and in foreign language affect the EFL 
186 Celt, Volume 13, Number 2, December 2013: 155 - 186

learners' writing accuracy differently?'In European Online Journal of Natural and Social Sciences, Vol. 2, No. 2, 2013.

Salem Saleh Khalaf Ibnian. "Brainstorming and Essay Writing in EFL Class". In Theory and Practice in Language Studies, Vol. 1, No. 3, 2011:263-272.

Sheen, Y. "The effect of focused written corrective feedback and language aptitude on ESL learners' acquisition of articles". In TESOL Quarterly, Vol. 41, 2007:255-283.

Truscott, J. "The case against grammar correction in L2 writing classes". In Language Learning, Vol. 46, 1996:327-369. 